UDC 573.6.086:633.16; https://doi.org/10.37878/2708-0080/2021-4.07

\title{
STABILITY OF PHYTOCENOSES IN OIL-PRODUCING REGIONS
}

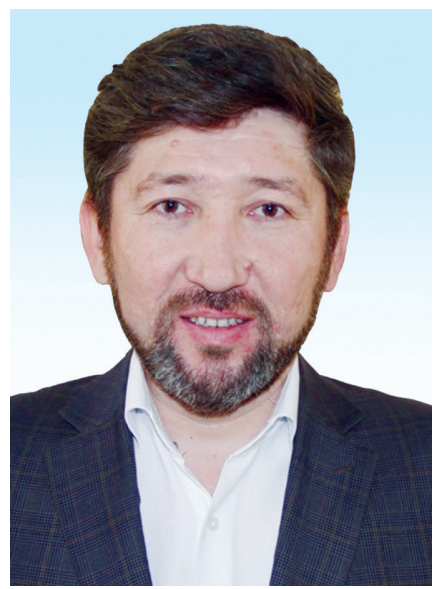

YE.O. DOSZHANOV ${ }^{1 *}$, $\mathrm{PhD}$, Associate Professor of the Department of UNESCO for sustainable development, https://orcid.org/0000-00023454-8889

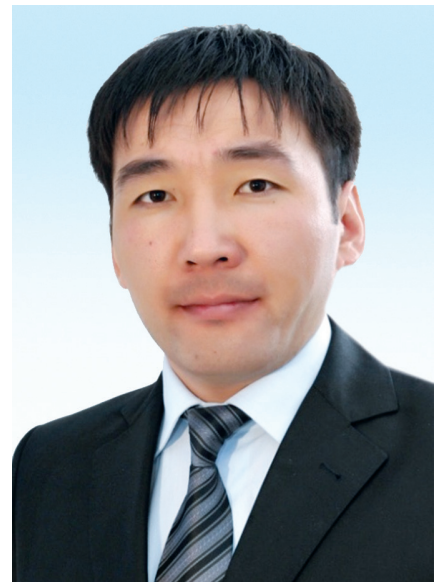

K.K. KUDAIBERGENOV ${ }^{1}$, PhD., Senior Lecturer of the Department of Chemical Physics and Materials Science, https://orcid.org/0000-00025444-0314

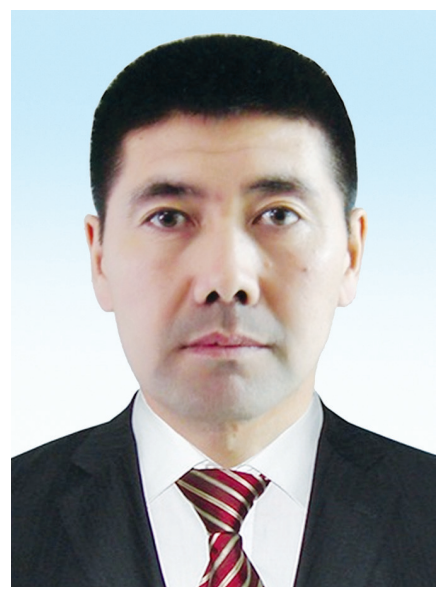

YE. TILEUBERDI ${ }^{1}$,

$\mathrm{PhD}$, Associate Professor of the Department of Chemical

Physics and Materials Science,

https://orcid.org/0000-00019733-5015

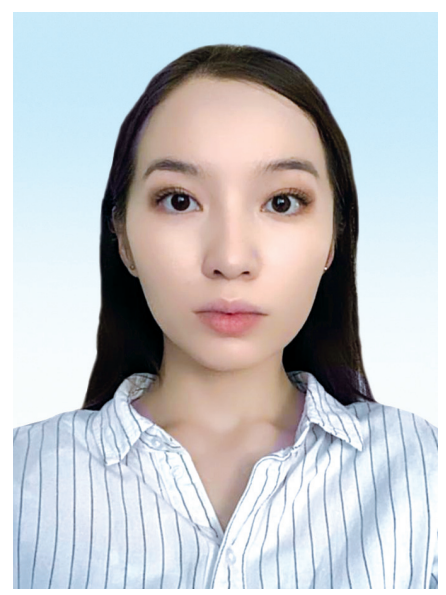

A. NURTILEU 1 , Master's Degree Student of the Department of UNESCO for sustainable development, https://orcid.org/0000-00034291-7469

* Адрес для переписки. E-mail: doszhanov_yerlan@mail.ru 
${ }^{1}$ AL-FARABI KAZAKH NATIONAL UNIVERSITY, 71, al-Farabi Ave., Almaty, 050040, Republic of Kazakhstan

The only real way to deal with the consequences of oil and oil products spills is a complex of works, including mechanical or physico-chemical removal of spilled oil products with subsequent purification of the remaining oil in the soil by biological methods using phytoremediation with oil-oxidizing plants.

One of the stages of the study of hydrocarbon-oxidizing plants before their introduction into the environment for remediation of contaminated sites is the study of the process of degradation of pollutants in model soil systems.

Model experiments on cleaning and restoration of soils after their contamination with oil and oil products by plant biomass were studied. Oil samples from the Tengiz field were taken. During the experiments, the indicator of the total amount of biomass, as well as the oil content in the soil, was controlled. To correctly assess the participation of plant raw materials in the destruction of oil, experiments were carried out using non-sterile soils. Among other plant cultures, the most degrading activity was shown by plant cultures of the genus Fabaceae, which led to an increase in growth in the soil environment by an average of $7 \mathrm{sm}$ in 20 days. This is observed for plants with oil concentrations of 3,6 and $9 \mathrm{~g}$.

The results of physical and chemical analyses of phytoremediation products of crude oil, petroleum products and individual aromatic hydrocarbons can be important in microbiological and chemical studies with geobotanical indicators that allow analyzing the mechanism of action of biomass in the process of phytoremediation in the disposal of oil waste that pollutes the environment.

The available data on the effect of petroleum hydrocarbons on plants are very contradictory. The species diversity of plants capable of growing on oil-contaminated soils has not been sufficiently studied. Knowledge of the degree of resistance of plants to hydrocarbon pollution is necessary to address issues related, on the one hand, to the possibility of their cultivation on contaminated soil, and on the other - to use for the restoration of disturbed soil fertility.

In connection with the above, it is of great scientific and practical interest to study the effect of various doses of oil on changes in vegetation cover, soil properties and assessment of their phytotoxicity, which together determines the relevance of the stated topic.

KEY WORDS: phytocenosis, oil-contaminated soil, vegetation cover

\section{МҰНАЙ ӨНДІРУ АЙМАҚТАРЫНДА ФИТОЦЕНОЗДАРДЫН ТҰРАҚТЫЛЫҒЫ}

E.O. ДОСЖАНОВ ${ }^{1}$, доктор PhD., тұрақты даму бойынша ЮНЕСКО кафедрасының м.а. профрессоры, https://orcid.org/0000-0002-3454-8889

E. TIЛЕУБЕРДI' ${ }^{1}$ доктор PhD., химиялық фризика және материалтану кафедрасының доценті, https://orcid.org/0000-0001-9733-5015

К.К. ҚҰДАЙБЕРГЕНОВ ${ }^{1}$, доктор PhD., химиялық физика және материалтану кафредрасының аға оқытушысы, https://orcid.org/0000-0002-5444-0314

А. НҰРТІЛЕУ'1, тұрақты даму бойынша ЮНЕСКО кафедрасының магистранты, https://orcid. org/0000-0003-4291-7469

1ӘЛ-ФАРАБИ АТЫНДАҒЫ ҚАЗАҚ ҰЛТТЫҚ УНИВЕРСИТЕТІ, Қазақстан Республикасы, 050040, Алматы қ., әл-Фараби даң., 71

Мұнай мен мұнай өнімдерінің төгілу салдарымен күресудің қазіргі кездегі жалғыз нақты әдісі, ол төгілген мұнай өнімдерін механикалық немесе физика-химиялық жолмен алып тастау, содан кейін топырақта қалған мұнайды биологиялық әдістермен мұнайға төзімді өсімдіктермен фриторемедиациялау арқылы тазарту. 
Мақалада ластанған жерлерді ремедиациялау үшін қоршаған ортаға енгізер алдында көмірсутекті тотықтыратын өсімдіктерді зерттеу кезеңдерінің бірі модельдік топырақ жүйелеріндегі ластаушы заттардың деградация процесін зерттеу болып табылады.

Топырақты мұнай және мұнай өнімдері Теңіз кен орындарынан алынып, өсімдік биомассаларымен ластағаннан кейін оларды тазарту және қалпына келтіру бойынша модельдік эксперименттер жүргізу зерттеленді. Эксперименттер барысында биомассаның жалпы санының көрсеткіші, сондай-ақ топырақтағы мұнай мөлшері бақыланды. Өсімдік шикізатының мұнайдың жойылуына қатысуын дұрыс бағалау үшін эксперименттер стерильді емес топырақты қолдану арқылы жүргізілді. Басқа өсімдік дақылдарының ішінде Fabaceae тұқымдасының өсімдік дақылдары ең деградациялық белсенділікті көрсетіп, бұл топырақтарда шамамен 20 күнде орта есеппен 7 см өсу динамикасы бақыланды. Бұл мұнай концентрациясы 3, 6 және 9 г өсімдіктер үшін байқалады.

Шикі мұнай, мұнай өнімдері және ароматты көмірсутектерді фриторемедиациялау өнімдерін фризика-химиялық талдаулардың нәтижелері геоботаникалық көрсеткіштері бар микробиологиялық және химиялық зерттеулерде маңызды болуы мүмкін, бұл қоршаған ортаны ластайтын мұнай қалдықтарын кәдеге жарату кезінде фриторемедиация процесінде биомассаның әсер ету механизмін талдауға мүмкіндік береді.

Мұнай көмірсутектерінің өсімдіктерге әсер етуіне қатысты қолда бар деректер өте қарама-қайшы. Мұнаймен ластанған топырақтарда өсетін өсімдіктердің түрлерінің әртүрлілігі жеткіліксіз зерттелген. Өсімдіктердің көмірсутектің ластануына төзімділік дәрежесін білу, бір жағынан, оларды ластанған топырақта өсіру мүмкіндігімен, екінші жағынан, бұзылған топырақ құнарлылығын қалпына келтіру үшін пайдалану арқылы байланысты мәселелерді шешу үшін қажет.

Жоғарыда айтылғандарға байланысты мұнайдың әртүрлі дозаларының өсімдік жамылғысының өзгеруіне, топырақтың қасиеттеріне әсерін зерттеу және олардың фритотоксикалығын бағалау үлкен ғылыми және практикалық қызығушылық тудырады, бұл дегеніміз, берілген тақырыптың өзектілігін анықтайды.

ТҮЙІн СӨзДЕР: фритоценоз, мұнаймен ластанған топырақтар, өсімдік жамылғысы.

\section{УСТОЙЧИВОСТЬ ФИТОЦЕНОЗОВ В РАЙОНАХ ДОБЫЧИ НЕФТИ}

E.О. ДОСЖАНОВ ${ }^{1}$, доктор PhD., и.о. профрессора кафедры ЮНЕСКО по устойчивому развитию, https://orcid.org/0000-0002-3454-8889

E. ТІЛЕУБЕРДI' ${ }^{1}$ доктор PhD., доцент кафедры химической фризики и материаловедения, https:// orcid.org/0000-0001-9733-5015

К.К. КУДАЙБЕРГЕНОВ ${ }^{1}$, доктор PhD., старший преподаватель кафедры химической фризики и материаловедения, https://orcid.org/0000-0002-5444-0314

А. НҰРТІЛЕУ' ${ }^{1}$ магистрант кафедры ЮНЕСКО по устойчивому развитию, https://orcid.org/00000003-4291-7469

${ }^{1}$ КАЗАХСКИЙ НАЦИОНАЛЬНЫЙ УНИВЕРСИТЕТ ИМЕНИ АЛЬ-ФАРАБИ, Республика Казахстан, 050040, г. Алматы, пр. аль-Фараби, 71

Единственным реальным способом борьбы с последствиями разлива нефтти и нефртепродуктов в настоящее время является комплекс работ, включающий механическое или фризико-химическое удаление разлитых нефртепродуктов с последующей очисткой остающейся в почве нефти биологическими методами при помощи фриторемедиации нефтеокисляющими растениями.

В статье приведен один из этапов исследования углеводородокисляющих растений перед их интродукцией в окружающую среду для ремедиации загрязненных участков, что является целью изучения процесса деградации поллютантов в модельных почвенных системах. 
Изучено проведения модельных экспериментов по очистке и восстановлению почв после загрязнения их нефтью и нефртепродуктами растительными биомассами, для чего были отобраны пробы нефтти Тенгизского месторождения. В ходе экспериментов контролировали показатель общей численности биомассы, а также содержание нефрти в почве. Для правильной оценки участия растительного сырья в деструкции нефрти эксперименты проводились с использованием нестерильных почв. Среди остальных растительных культур наибольшую деградирующую активность показали растительные культуры рода Fabaceae, которые привели к повышению роста в почвенной среде в среднем 7 см за 20 суток. Это наблюдается для растений с концентрацией нефрти 3, 6 и 9 г.

Приведены результаты фризико-химических анализов продуктов фриторемедиации сырой нефти, нефртепродуктов и индивидуальных ароматических углеводородов, которые могут иметь важное значение в микробиологических и химических исследованиях с геоботаническими показателями, позволяющие анализировать механизм действия биомассы в процессе фриторемедиации при утилизации нефртяных отходов, загрязняющих окружающую среду.

Имеющиеся данные в отношении действия углеводородов нефти на растения весьма противоречивы. Недостаточно изучено видовое разнообразие растений, способных произрастать на нефтезагрязненных почвах. Знание степени устойчивости растений к углеводородному загрязнению необходимо для решения вопросов, связанных, с одной стороны, с возможностью их возделывания на загрязненной почве, а с другой - с использованием для восстановления нарушенного почвенного плодородия.

В связи с выше изложенным, большой научный и практический интерес представляет изучение влияния различных доз нефти на изменение растительного покрова, свойства почв и оценка их фритотоксичности, что в совокупности определяет актуальность заявленной темы.

КЛЮЧЕВЫЕ СЛОВА: фитоценоз, нефртезагрязненная почва, растительный покров.

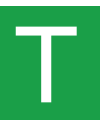

he vegetation cover is the most important component of the landscape, flexible and responsive to changes in environmental conditions. Plant communities are a reliable indicator of the nature and degree of soil cover degradation. Compared to meadow vegetation, steppe vegetation is more resistant to soil over consolidation. The stability of phytocenoses is the most important function of the structure of the biosystem, since the structure, ultimately, is a set of stable connections of the object $[1,2]$. At the same time, the study of the conditions for sustainable existence and development of biosystems is of great applied value, since it is the presence of a stable trajectory of an object in the phase space of environmental factors that is the basis for an adequate assessment of the state of an object and predicting its changes when varying the intensity of action of external and internal factors. The phenomenon of stability can be considered in relation to systems of different levels. A phytocenosis is an elementary area of vegetation, for which it is characteristic: relative uniformity in appearance, species composition, structure, a relatively similar system of relationships between populations of plant species and the habitat, and which can exist independently outside the given environment [3].

Problems of stability of biosystems have long been the object of close attention of researchers. Long-term discussions about the essence of sustainability have led to the emergence of a large number of different approaches and as a consequence of the lack of a unified view of the nature of this phenomenon. The analysis allows us to identify several main approaches to understanding sustainability. The most general definition belongs to M.A. Glazovskaya: stability, as the ability to preserve a given object for some time. Another fairly general definition belongs to K. Waddington: stability, as the ability to maintain the development trajectory of an object [4]. 
The resistance of plants to toxic substances is different within the genus, species, and even the population, in the same plant at different stages of development. Many modern studies are associated with the study and identification of signs of plant resistance, in particular, physiological-biochemical, anatomical-morphological, genetic $[5,6]$.

Characteristics of pigment systems and intensity of photosynthesis. The entry of toxic substances into the root system and stems is accompanied by a decrease in the buffer capacity. The accumulation of toxic substances leads to the destruction and decay of pigments.

Under the biological resistance of the plantation Sergeichik S.A. understood the ability to withstand unfavorable environmental conditions with the least loss of trees that retain the maximum longevity and duration of growth. At the same time, it was proposed to classify plantations as stable when they have the following forest biological properties: the ability to withstand unfavorable conditions of growth and development, in which the possibility of premature decay and withering away, the replacement of some species by others is excluded. The signs of the stability of the biocenosis are the constancy of the number of species in it and the small amplitude of fluctuations in the number of its populations. The presence of conjugate resistance of plants to gases and other extreme environmental factors was emphasized by P.A. Genkel. The positive value of drought resistance and winter hardiness for the gas resistance of plants is included in the use of xeromorphic structures as a protective barrier against toxicants [7].

Environmental pollution from industrial emissions cannot be regarded as a new environmental factor. In the literature, the stability of natural systems is considered as the ability for a long, but not endless accumulation of harmful effects without visible harm to the system. The degree of variability of individuals of the population depends on the extremeness of the impact, and, with an increase in the strength of the factor, the average damageability of plants increases and, at the same time, the level of variability decreases.

The reaction of plants to an unfavorable effect consists of two phases - reaction and recovery. In turn, for the recovery period, the processes of neoplasm are characteristic of both physiological and sometimes morphological and anatomical character. Yu.Z. Kulagin determined that the gas resistance of plants cannot be reduced to any one function or structure, no matter how great their role in protecting against a toxicant $[7,8]$.

N.P. Krasinsky pointed to the involvement of various structural and physiological properties in the gas resistance, which act as prerequisites for varying degrees of damage, noting that the gas resistance of plants was not created in the process of evolution [9].

V.M. Ryabinin proposed by gas resistance to understand the ability of plants to maintain their viability under conditions of atmospheric air pollution with toxic gases due to general or individual anatomical, physiological and biological characteristics. Subsequently Yu.Z.Kulagin significantly expanded the types of gas resistance, bringing them to eight: anatomic, physiological, biochemical, gabitual, phenorhythmic, anabiotic, population, coenotic. Each type of resistance is based on mechanisms that ensure the reliability of the organism, different forms of restoration, reservation, adaptation of structures and functions at all levels of their physiological manifestation, and a certain type of resistance is formed as a composition of the main systems of plant reliability [11].

Woody plants, as a rule, are the first to react to unfavorable environmental factors. One of the reasons for this is the presence of a powerful trunk, which is a transport line 
between the crown and the root system for aqueous solutions. Shrubs, as a further stage of the adaptive evolution of woody plants to deteriorating environmental conditions, increased their multi-trunk and short stature more strongly, increased the number of renewal points [10].

According to G.M. Il'kun, the main criteria by which the selection of gas-resistant plants should be carried out include soil characteristics: the capacity of cation and anion exchange, the relation to soil salinity with chloride-sulfate salts. At the same time, the species, the phylogenetic fitness of which is associated with acidic and moist soils, are less gas-resistant and, on the contrary, more gas-resistant plants grown on soils saline with chloride-sulfate salts. The accumulation of alkaline and alkaline earth elements $(\mathrm{K}$, $\mathrm{Ca}, \mathrm{Mg}$ ) can increase the buffer capacity of the cytoplasm and cell sap and contribute to the neutralization of absorbed anions $\left(\mathrm{SO}_{2}\right.$ and $\left.\mathrm{NOx}\right)$. The saturation of cells with free mineral cations restrains the onset of irreversible changes in them. Up to a certain threshold, phytopathological changes are reversible, and when the external influence is removed, they are restored [10].

In this way, vegetation under the direct impact of oil dies completely, however, complete degradation of vegetation is observed extremely rarely. Long-lived tree species have a strong and rather deep root system, so they are less vulnerable to the direct impact of surface oil spills; at the same time, the period of development of cenoses up to the stage of the climax community can last up to several hundred years. As for the steppe vegetation, it takes less time for the formation of a vegetation cover consisting of shortlived species than for a cover with long-lived tree species [10,11].

Petroleum bitumens have a great influence on cell division and plant growth; in addition to bitumen, an important role belongs to the elements present in oil waters, often accompanying oil - boron, iodine, bromine. Therefore, plants undergo strong changes when oil gets directly onto them or into the soil. Plants become painfully swollen, with a deformed stem, completely without leaves or with leaves turned into shapeless outgrowths $[12,13]$.

\section{Vegetation cover dynamics and phytotoxicity of oil-contaminated soils}

At the end of the study, the vegetation of the control plot remained unchanged. The total projective cover was $70-60 \%$. The height of aboveground shoots in the communities decreased to $20-25 \mathrm{~cm}$, which is apparently related to the weather conditions of the study year. Floristic richness is represented by 4 types on the description site. The families Poaceae and Fabaceae also continue to dominate. The value of the underground phytomass was 1.3 times higher than the aboveground one and amounted to $179.5 \mathrm{~g} / \mathrm{m}^{2}$. The total reserves of phytomass are $259.1 \mathrm{~g} / \mathrm{m}^{2}$.

In areas with $3 \%$ pollution, the residual oil content reaches an acceptable level. Geobotanical indicators of the studied areas with a contamination dose of $3 \%$ are close to those in the control uncontaminated area. Samples with 6,12 and $18 \%$ oil doses still demonstrate a decrease in the projective cover up to $15 \%$, the average height of the grass stand up to $7 \mathrm{~cm}$, aboveground and underground biomass up to $29.4 \mathrm{~g} / \mathrm{m}^{2}$ and $36.7 \mathrm{~g} / \mathrm{m}^{2}$, respectively, and reduction of humus reserves to $66.1 \mathrm{~g} / \mathrm{m}^{2}$.

At the site with a $3 \%$ dose of oil, the processes of suppression of natural vegetation cease and biomass, such indicators as phytomass, the height of herbage do not differ much 
from areas not contaminated with oil products. In areas with a higher concentration of oil, the tendency to oppression of vegetation is more pronounced (table 1).

With a decrease in the concentration of oil pollution, cereals appear first on the recovering soil, which disappeared at an early stage.

The dynamics of geobotanical indicators of areas contaminated with various doses of oil is presented in table 2 .

Table 1 - Dynamics of geobotanical indicators of areas contaminated with different doses of oil

\begin{tabular}{|c|c|c|c|c|c|c|c|}
\hline \multirow[b]{2}{*}{ 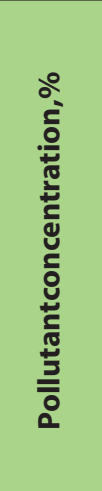 } & \multirow[b]{2}{*}{ 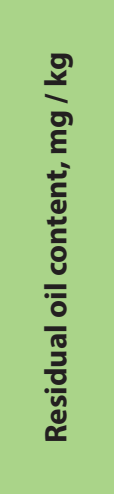 } & \multicolumn{6}{|c|}{ Geobotanical indicators } \\
\hline & & 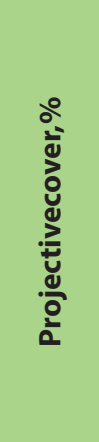 & 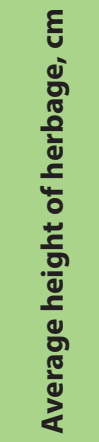 & 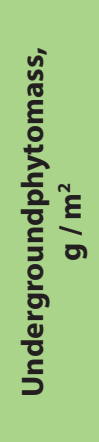 & 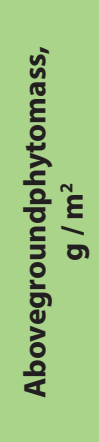 & 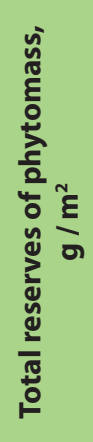 & 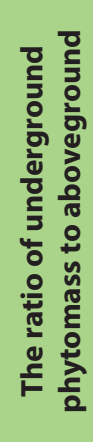 \\
\hline $\begin{array}{c}\text { control } \\
(0 \%)\end{array}$ & $3 \pm$ & $75-65$ & $50-45$ & 198 & 86.4 & 284.4 & 2.3 \\
\hline $3 \%$ & $2563 \pm$ & $60-55$ & $35-20$ & 190.2 & 82.5 & 272.7 & 2.3 \\
\hline $6 \%$ & $4892 \pm$ & $50-35$ & $18-15$ & 98.3 & 75.4 & 173.7 & 1.3 \\
\hline $9 \%$ & $11255 \pm$ & $25-20$ & $16-12$ & 74.1 & 58.7 & 132.8 & 1.3 \\
\hline
\end{tabular}

Table 2 - Correlation dependence of geobotanical indicators on the physical properties of oil-contaminated soils

\begin{tabular}{|c|c|c|c|}
\hline $\begin{array}{c}\text { Physical properties } \\
\text { of soils }\end{array}$ & \multirow{2}{*}{ Soildensity } & \multirow{2}{*}{$\begin{array}{l}\text { Water permeability } \\
\text { of soil }\end{array}$} & \multirow{2}{*}{$\begin{array}{l}\text { Residual oil content } \\
\text { in soil }\end{array}$} \\
\hline Geobotanical indicators & & & \\
\hline \multicolumn{4}{|c|}{2018 year } \\
\hline projective cover & $r=0.76, p=0.001$ & $r=0.79, p=0.003$ & $r=-0.72, p=0.005$ \\
\hline average height of herbage & $r=0.82, p=0.013$ & $r=0.78, p=0.007$ & $r=-0.75, p=0.003$ \\
\hline total reserves of phytomass & $r=0.84, p=0.004$ & $r=0.83, p=0.011$ & $r=-0.81, p=0.007$ \\
\hline \multicolumn{4}{|c|}{2019 year } \\
\hline projective cover & $r=0.71, p=0.004$ & - & - \\
\hline average height of herbage & - & $r=0.75, p=0.006$ & - \\
\hline total reserves of phytomass & $r=0.73, p=0.004$ & $r=0.80, p=0.004$ & $r=-0.74, p=0.008$ \\
\hline
\end{tabular}

Correlation analysis data showed a close relationship between the geobotanical parameters of oil-contaminated areas with the physical properties of these soils. Table 2 shows that in 2018 the correlation dependence is closer than in 2019. This indicates that in 2019 there was a partial recovery of soil after pollution. As a result, changes in some factors have become not so significant as to affect the growth and development of natural vegetation. 


\section{экология}

Thus, the results of the study showed that representatives of the Fabaceae family are the most resistant plant species. According to many authors, legumes and some types of greens are used as phytomeliorants for oil-contaminated soils.

\section{REFERENCES}

1 Bondarenko A.N. Estimates of oil contamination of soils in arid territories (on the example of the Astrakhan region) // Avtoreferat, - 2008. - P. 24.

2 Kireeva N.A. Monitoring of the growth and development of plants used for phytoremediation of oil-contaminated soils // Ecology and Industry of Russia. - 2007. - No.9. - P. 46-47.

3 AvdeevV.I. Methodological aspects of studying the composition and vitality of plant populations // Transaction Institute of Bioresources and Applied Ecology. - 2005. - No.5. - P. 20-24.

4 Influence of the MicrozymeTMBiodestructor on the Phytotoxicity of Oil Pollution // Oil and gas. - 2013. - № 2. - P. 123-125.

5 OngarbaevYe.K.,DoszhanovYe.O., Mansurov Z.A. Processing of heavy hydrocarbons and waste. - Ed. 3rd, addition. - Almaty: Kazakh University. 2017. - 498 p.

6 Medvedev S.S. Plant Physiology: Textbook / S.S. Medvedev - St.Petersburg: Publishing house of St.Petersburguniversity. - 2004. - P. 336.

7 Kireeva N.A., Vodopyanov V.V., Shamaeva A.A., Grigoriadi A.S. Dynamics of phytoremediation the soils, contaminated with oil // Soil remediation / ed. L.Aachen, P.Eichmann. N-Y.: Nova Science Publishers. - 2009. - P. 369-377.

8 Kalyuzhin V.A., Nyrzhanova C.B. Development of new methods for bio-utilization of oil waste // Oil and gas. - 2014. - № 6. - P. 121-127.

9 Nemereshina O.N. To the study of bioecological features of Polygonumaviculare L. Steppe Ural region // Biological formation and bioresources of the Ural and adjacent territories. Materials of the international conference. - Orenburg: Print-service, 2006. - P. 94-96.].

10 Doszhanov E.O., Syulyan Ch., Myktybay P. Phytoremediation of soils contaminated // Oil and Gas. - 2018. - No. 3(105). - P. 133-141.

11 Ryabinina Z.N., Safonov M.A. Preservation of rare species of plants and fungi of the Orenburg region: problems, experience, prospects. - Ekaterinburg: Ural Branch of the Russian Academy of Sciences, 2007. P. 118.

12 Tarshis L.G. Underground plant organs as additional indicators of the properties of substrates of technogenic landscapes // Fundamental and Applied Ecology: Problems of Urbanization / Materials of an International Scientific Conference. - Ekaterinburg: Ural Publishing House University, 2013. P. 338-341.

13 Doszhanov Ye.O., Tileuberdi Ye., Kudaibergenov K.K., Ongarbaev Ye.K., Mansurov Z.A., Zhybanova A.A. Research of vegetable crops on oil contaminated soils // Tenth international scientific Nadirov's reading on the problem «Scientific and technological development of oil and gas complex». 27-28 September 2012. - Atyrau. - P. 520-522. 